\title{
Experimental study of the effect of the design features of frame partitions on their sound insulation
}

\author{
Michael V asilyev*, Anatoly Gerasimov, and Nikita Rud \\ State U niversity of Civil Engineering - National Research U niversity, M oscow, Russia
}

\begin{abstract}
This paper presents an experimental comparison of various multilayer frame-sheathing structures and describes the effect of their design features on their own sound insulation. The paper discusses the dependence of sound insulation on material and type of the frame, the amount and density of the filler, the number and type of facing layers, the presence of a damping layer and a divided base.
\end{abstract}

\section{Introduction}

Undoubtedly, the human environment acoustics affects not only the emotions and moods of people, but also their health [1], therefore, designing the internal volumes of buildings and structures, it is extremely important to take into account the factors of the future comfortable stay of people inside them. There are mandatory (minimum) requirements for the internal environment of the building [2], one of which is the requirements for architectural and construction acoustics, standardized by Set of rules 51.13330.2011 "Sound protection" [3].

In order to reduce the loads on the supporting structures of the building and the construction cost, blocks of various densities are used for the construction of partitions (usually no more than $600-800 \mathrm{~kg} / \mathrm{m}^{3}$ ). However, as shown by several studies $[4,5]$, the requirements for sound insulation of structures made of such materials are not always met. It is especially important to take this into account when designing sound insulation for hotels, office premises, conference rooms, cinemas, etc.In this regard, the purpose of this comparison is an experimental study of the effect of the design features of frame-sheathing structures on their sound insulation: analysis of the effect of the physical and mechanical characteristics of the material, the type and shape of frame stud profiles, facings and fillers and the presence of perimeter damping on the sound insulation of frame-sheathing partitions. The protocols of laboratory measurements of the own sound insulation of various multilayer frame-sheathing structures were used for comparison. The measurements were carried out according to the GOST 27296-87 "Noise protection in construction. Sound insulation of building envelopes. Measurement methods" standard method [4].

*Correspondingauthor:mick03vasil@ mail.ru 


\section{Research of influence}

\subsection{Effect of the partition frame material}

To study the effect of the frame material on the sound insulation of the entire framesheathing structure, two fragments of the partition with dimensions of $2000 \times 1200 \mathrm{~mm}$ on single frames are considered: 1 - from a timber of $75 \times 50 \mathrm{~mm}$ in size, 2 - from a metal profile PS 75/50 and PN 75/37, $0.6 \mathrm{~mm}$ thick, sheathed on each side with 1 gypsum fiber board with surface density of $15 \mathrm{~kg} / \mathrm{m}^{2}$ and thickness of $12.5 \mathrm{~mm}$ each, without filling the internal space. The structures are installed using damping gaskets made of glass-fiber mat, $8 \mathrm{~mm}$ thick, the perimeter joints are treated with silicone sealant.
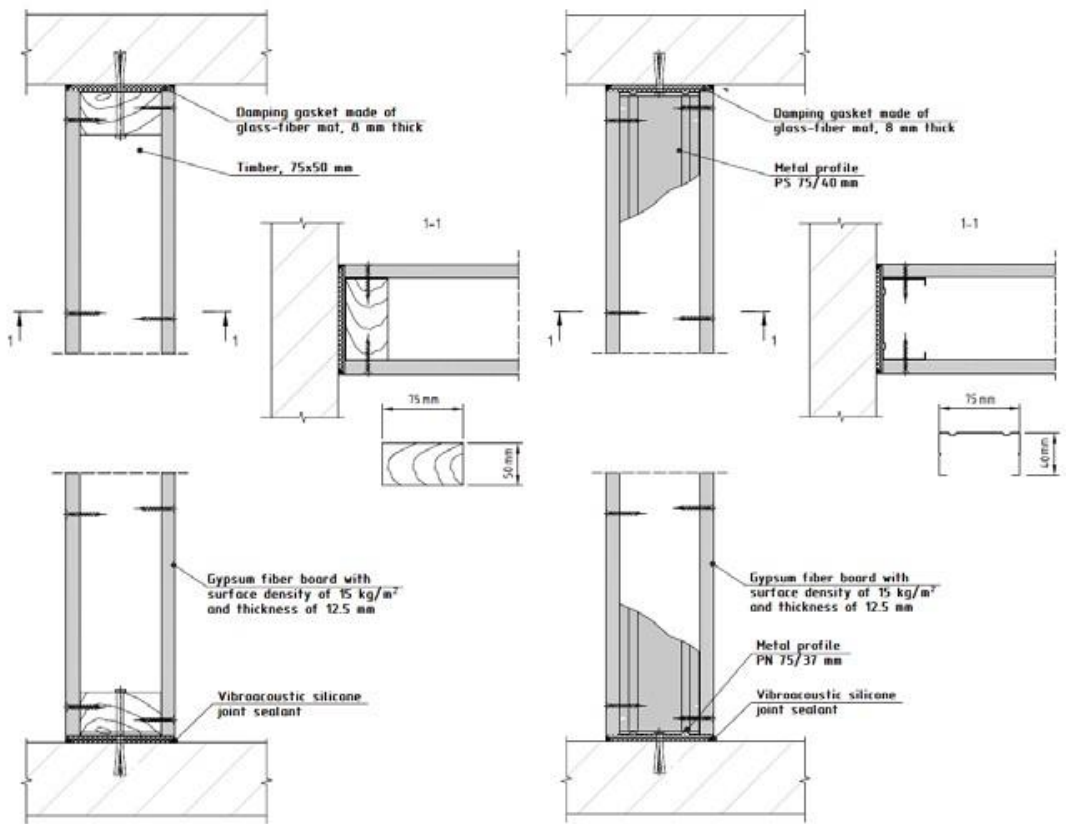

Fig. 1. Diagram of constructing the frame partition: 1 - from a timber of $75 \times 50 \mathrm{~mm}$ in size, 2 - from a metal profile PS 75/50 and PN 75/37, $0.6 \mathrm{~mm}$ thick.

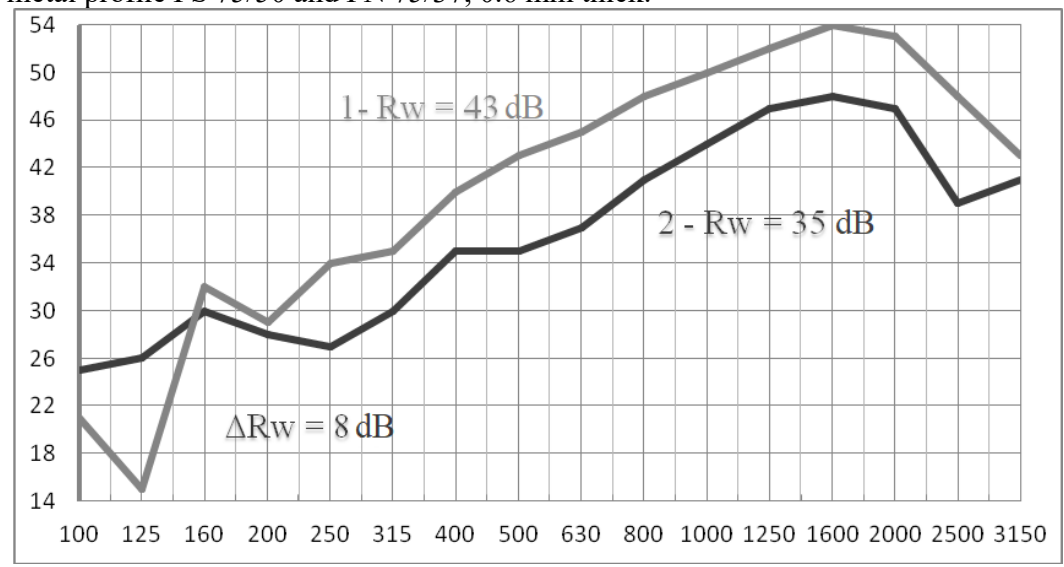

Fig. 2. The effect of the frame material on the sound insulation of the frame partition: 1 - from a timber of $75 \times 50 \mathrm{~mm}$ in size, 2 - from a metal profile PS 75/50 and PN 75/37, $0.6 \mathrm{~mm}$ thick. 
As we can see from Fig. 2, the difference between the sound insulation indices of partitions mounted on a wooden and metal frame reaches $8 \mathrm{~dB}$. There is no doubt that constructing a partition of the same thickness and the same materials, but on a metal frame, will be more effective.

\subsection{Effect of the profile type of the partition metal frame}

To study the effect of the type of metal frame profile on the sound insulation of the entire frame-sheathing structure, two fragments of a partition with dimensions of $2000 \times 1200$ mm on single frames are considered: 1 - PS 100/40 mm, PN 100/37 mm, $0.6 \mathrm{~mm}$ thick, 2 PS 95/50 mm, PN 95/37 mm, $0.46 \mathrm{~mm}$ thick, sheathed on each side with 2 gypsum fiber boards with surface density of $12 \mathrm{~kg} / \mathrm{m}^{2}$ and thickness of $12.5 \mathrm{~mm}$ each, with filling the inner space with sound-absorbing mineral wool plates with density of $35 \mathrm{~kg} / \mathrm{m}^{3}, 50 \mathrm{~mm}$ thick in two layers. The structures are installed using damping gaskets made of glass-fiber mat, $8 \mathrm{~mm}$ thick, the perimeter joints are treated with silicone sealant.

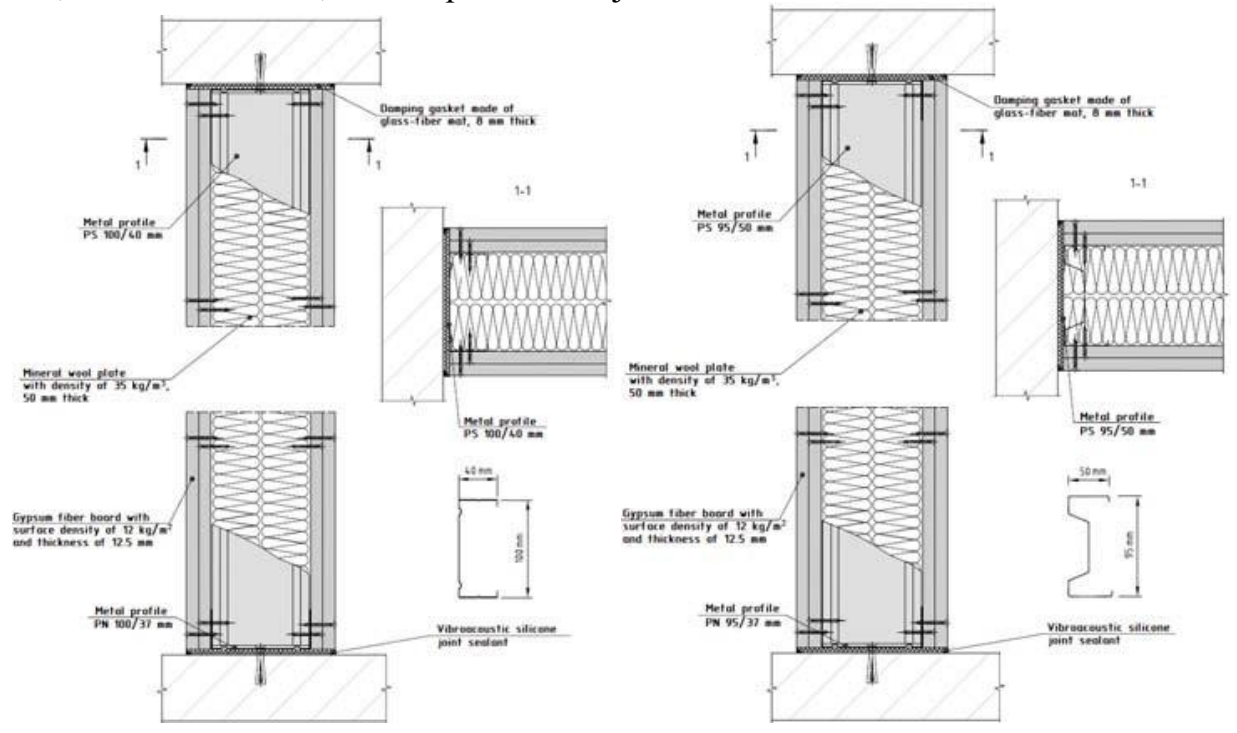

Fig. 3. Diagram of constructing the frame partition: 1 - PS 100/40 mm, PN 100/37 mm, $0.6 \mathrm{~mm}$ thick, 2 - PS 95/50 mm, PN 95/37 mm, $0.46 \mathrm{~mm}$ thick.

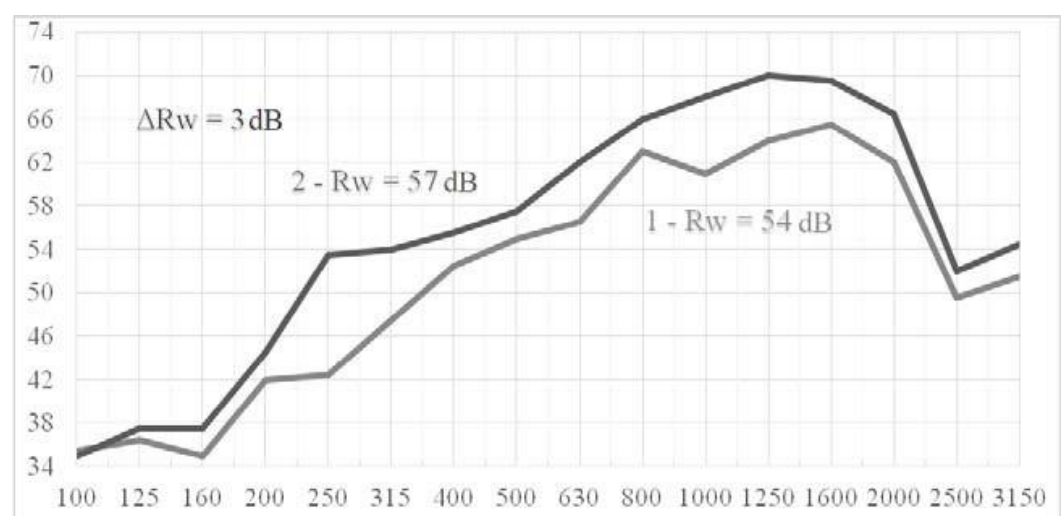

Fig. 4. Effect of the metal frame profile type on the sound insulation of a frame partition: 1 - PS 100/40 $\mathrm{mm}, \mathrm{PN} 100 / 37 \mathrm{~mm}, 0.6 \mathrm{~mm}$ thick, 2 - PS $95 / 50 \mathrm{~mm}$, PN 95/37 mm, $0.46 \mathrm{~mm}$ thick. 
Obviously, a partition made on a $\sum$ - section metal frame is more effective - this is due to the different stiffness of metal profiles. At that, $\Delta \mathrm{Rw}$ reaches $3 \mathrm{~dB}$, and in some frequency bands the difference reaches $6-12 \mathrm{~dB}$.

\subsection{Effect of the number of partition FACING sheets}

To study the effect of the number of facing sheets on the sound insulation of the entire frame-sheathing structure, fragments of partitions with dimensions of $2000 \times 1200 \mathrm{~mm}$ on a single frame made of a metal profile PS 50/40 mm, PN 50/37 mm, $0.6 \mathrm{~mm}$ thick are considered, with filling the inner space with sound-absorbing mineral wool plates with density of $35 \mathrm{~kg} / \mathrm{m}^{3}, 50 \mathrm{~mm}$ thick in one layer, sheathed on each side with gypsum fiber board with surface density of $12 \mathrm{~kg} / \mathrm{m}^{2}$ and thickness of $12.5 \mathrm{~mm}$ each: $1-2$ sheets on each side, $2-2$ and 3 sheets on each side, $3-3$ sheets on each side. The structures are installed using damping gaskets made of glass-fiber mat, $8 \mathrm{~mm}$ thick, the perimeter joints are treated with silicone sealant.

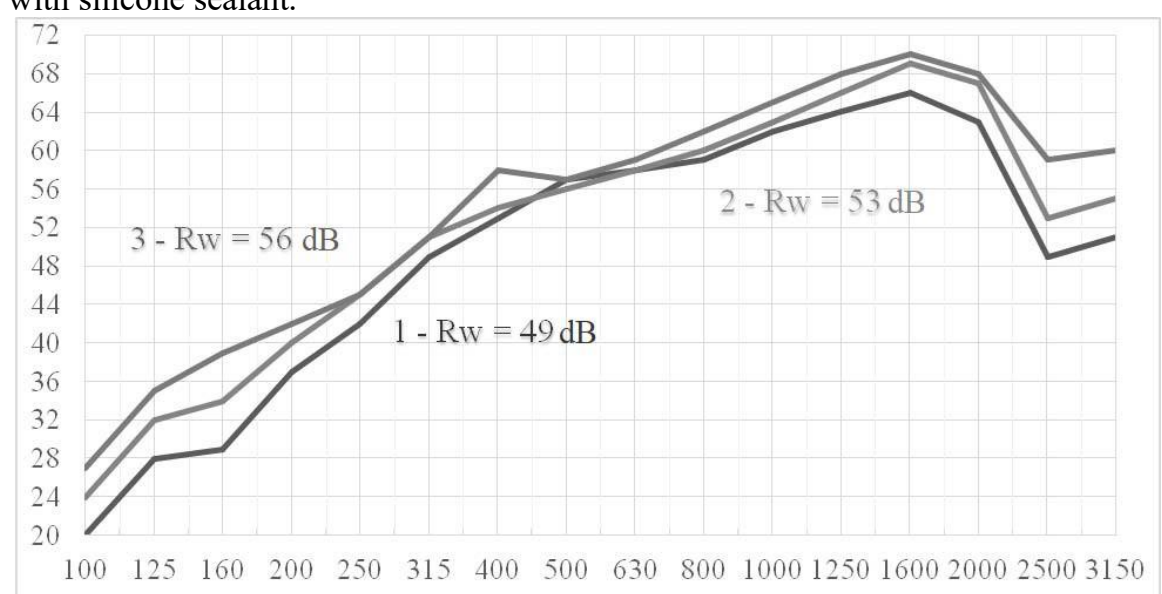

Fig. 5. Effect of the number of facing sheets: $1-2$ sheets on each side, $2-2$ and 3 sheets on each side, $3-3$ sheets on each side.

As we can see from fig. 5, with an increase in the number of facing sheets, the surface density of the structure increases, therefore, the efficiency of the structure increases according to the mass law [7], which is especially important for the sound insulation of low-frequency noise, where the increase in sound insulation in certain frequency bands reaches $8-10 \mathrm{~dB}$.

\subsection{Effect of the width of the air gap between the profiles of the double frame}

To study the effect of the width of the air gap between the profiles of the double frame, fragments of partitions with dimensions of $2000 \times 1200 \mathrm{~mm}$ on a double independent frame made of PS 100/40 mm, PN 100/37 mm, $0.6 \mathrm{~mm}$ thick are considered (distance between the frame profiles: $1-10 \mathrm{~mm}, 2-30 \mathrm{~mm}, 3-150 \mathrm{~mm}$ ), sheathed on each side with 2 gypsum fiber boards with surface density of $12 \mathrm{~kg} / \mathrm{m}^{2}$ and thickness of $12.5 \mathrm{~mm}$ each, with filling the inner space with sound-absorbing mineral wool plate with density of $35 \mathrm{~kg} / \mathrm{m}^{3}, 50 \mathrm{~mm}$ thick in two layers. The structures are installed using damping gaskets made of glass-fiber mat, $8 \mathrm{~mm}$ thick, the perimeter joints are treated with silicone sealant. 


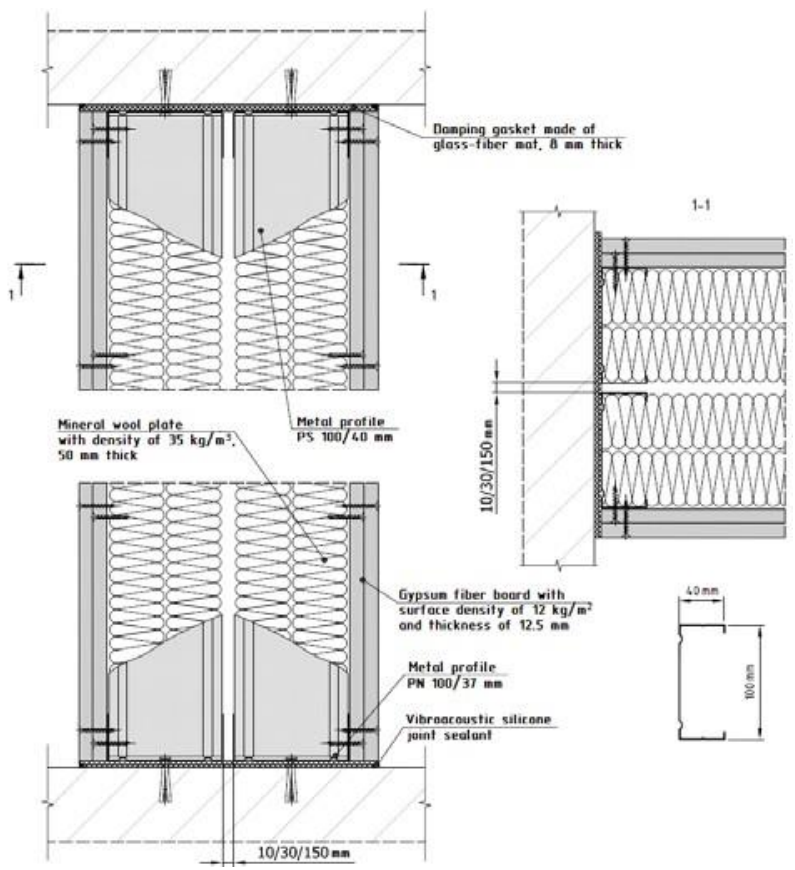

Fig. 6. Diagram of constructing the frame partition on a double metal frame with the air gap: $1-10 \mathrm{~mm}$, $2-30 \mathrm{~mm}, 3-150 \mathrm{~mm}$.

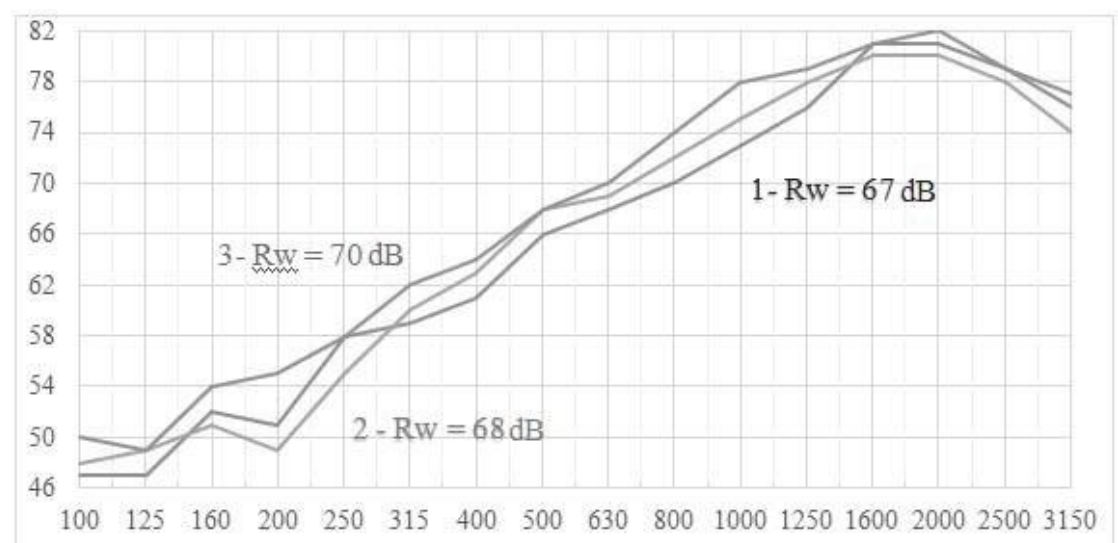

Fig. 7. Diagram of constructing the frame partition on a double metal frame with the air gap: $1-10 \mathrm{~mm}$, $2-30 \mathrm{~mm}, 3-150 \mathrm{~mm}$.

\subsection{Effect of damping along the perimeter of the frame partition}

To study the effect of damping of the frame-sheathing structure on its sound insulation, two fragments of a partition with dimensions of $2000 \times 1200 \mathrm{~mm}$ on double frames made of PS $50 / 40 \mathrm{~mm}$, PN 50/37 mm, $0.6 \mathrm{~mm}$ thick are considered, sheathed on each side with 2 gypsum fiber boards with surface density of $12 \mathrm{~kg} / \mathrm{m}^{2}$ and thickness of $12.5 \mathrm{~mm}$ with filling with mineral wool plates with density of $30 \mathrm{~kg} / \mathrm{m}^{3}, 50 \mathrm{~mm}$ thick in two layers: 1 - the partition is installed using damping gasket made of glass-fiber mat, $8 \mathrm{~mm}$ thick, the perimeter joint is treated with silicone sealant, 2 - without damping gasket, the perimeter joint is sealed with gypsum putty. 


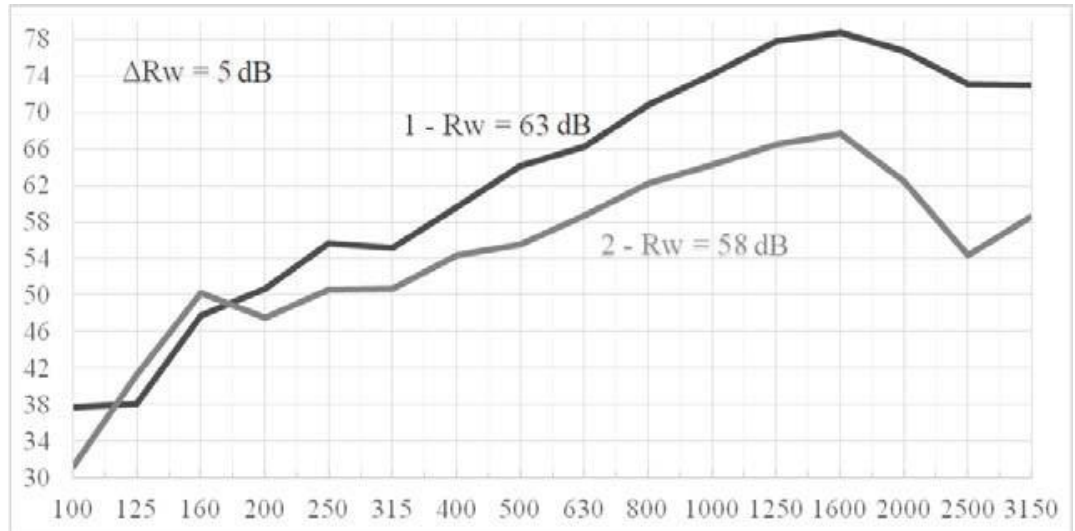

Fig. 8. Effect of damping around the perimeter of the partition: 1 - the partition is installed using damping gasket, the joint is sealed around the perimeter; 2 - without damping gasket, the perimeter joint is sealed with gypsum putty.

From the graph in Fig. 8 it can be seen that the damping of the abutting joint of the frame partition around the perimeter is important: the difference between the efficiency of the two frame partitions starts already from $200 \mathrm{~Hz}$, is especially noticeable at medium and high frequencies, and $\Delta \mathrm{Rw}$ of the partition with a damping layer increases to $5 \mathrm{~dB}$.

\subsection{Effect of the presence of a sound-absorbing layer in the frame partition}

To study the effect of the presence of a sound-absorbing layer in a frame-sheathing structure on its sound insulation, two fragments of a partition with dimensions of $2000 \times 1200 \mathrm{~mm}$ on a single frame made of a metal profile PS 100/40 mm, PN 100/37 mm, $0.6 \mathrm{~mm}$ thick are considered, sheathed on each side with 1 gypsum fiber board with surface density of $12 \mathrm{~kg} / \mathrm{m}^{2}$ and thickness of $12.5 \mathrm{~mm}$ : 1 - without filling the inner space, 2 - with filling with sound-absorbing mineral wool plate with density of $30 \mathrm{~kg} / \mathrm{m}^{3}, 100 \mathrm{~mm}$ thick. The structures are installed using damping gaskets made of glass-fiber mat, $8 \mathrm{~mm}$ thick, the perimeter joints are treated with silicone sealant.

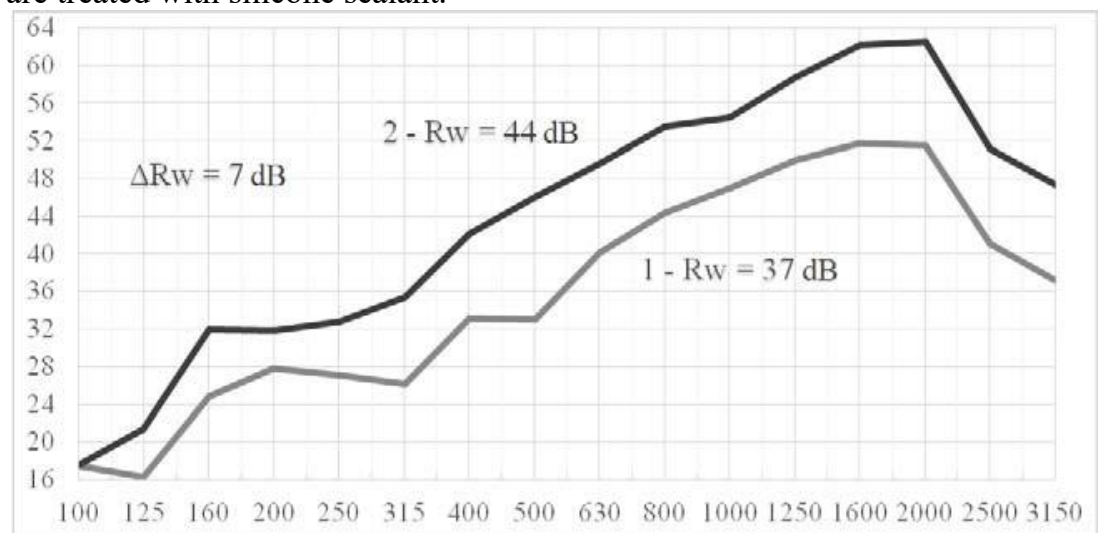

Fig. 9. Effect of the presence of the sound-absorbing layer: 1 - without filling the inner space, 2 - with filling with sound-absorbing mineral wool plate. 
The sound insulation graph shown in Fig. 9 confirms the correction from [7] for the presence of the sound-absorbing layer and, in this case, improves the efficiency of the frame facing up to $7 \mathrm{~dB}$.

\subsection{Effect of the density of the frame partition sound-absorbing layer}

To study the effect of the density of the filler of the frame-sheathing structure on its sound insulation, fragments of partitions with dimensions of $2000 \times 1200 \mathrm{~mm}$ on double frames made of PS 50/40 mm, PN 50/37 mm, $0.6 \mathrm{~mm}$ thick are considered, sheathed on each side with 2 gypsum fiber boards with surface density of $12 \mathrm{~kg} / \mathrm{m}^{2}$ and thickness of $12.5 \mathrm{~mm}$ with filling with mineral wool plates of various densities, $50 \mathrm{~mm}$ thick, in 2 layers: 1 - with a density of $30 \mathrm{~kg} / \mathrm{m}^{3}, 2$ - with a density of $35 \mathrm{~kg} / \mathrm{m}^{3}, 3$ - with a density of $47 \mathrm{~kg} / \mathrm{m}^{3}$. The structures are installed using damping gaskets made of glass-fiber mat, $8 \mathrm{~mm}$ thick, the perimeter joints are treated with silicone sealant.

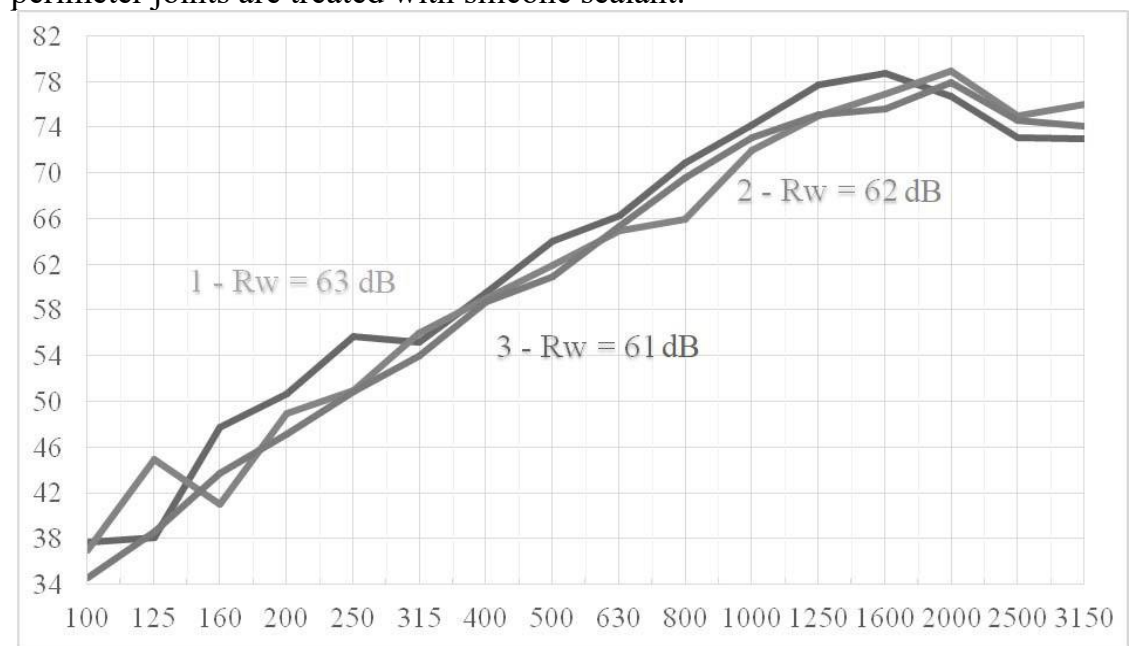

Fig. 10. Effect of the density of the sound-absorbing layer: 1 - with a density of $30 \mathrm{~kg} / \mathrm{m}^{3}, 2$ - with a density of $35 \mathrm{~kg} / \mathrm{m}^{3}, 3$ - with a density of $47 \mathrm{~kg} / \mathrm{m}^{3}$.

As we can see from the graph in Fig. 10, the density of the sound-absorbing layer affects the effectiveness of the sound insulation of the frame partition, as indicated in [7]; with a decrease in the density of the sound-absorbing material, the sound insulation index of the partition increases, but not much.

\subsection{Effect of the frame partition facing material}

To study the effect of the material of the facing sheets of the frame partition on its own sound insulation, two fragments of the partition with dimensions of $2000 \times 1200 \mathrm{~mm}$ on single frames made of PS 95/50 mm, PN 95/37 mm, $0.46 \mathrm{~mm}$ thick are considered, sheathed on each side with: $1-2$ gypsum fiber boards, with surface density of $12 \mathrm{~kg} / \mathrm{m}^{2}$ and thickness of $12.5 \mathrm{~mm}$ each, $2-2$ gypsum fiber boards, with surface density of 19.5 $\mathrm{kg} / \mathrm{m}^{2}$ and thickness of $15 \mathrm{~mm}$ each, with filling the internal space with sound-absorbing mineral wool plates with density of $35 \mathrm{~kg} / \mathrm{m}^{3}, 50 \mathrm{~mm}$ thick in two layers. The structures are installed using damping gaskets made of glass-fiber mat, $8 \mathrm{~mm}$ thick, the perimeter joints are treated with silicone sealant. 


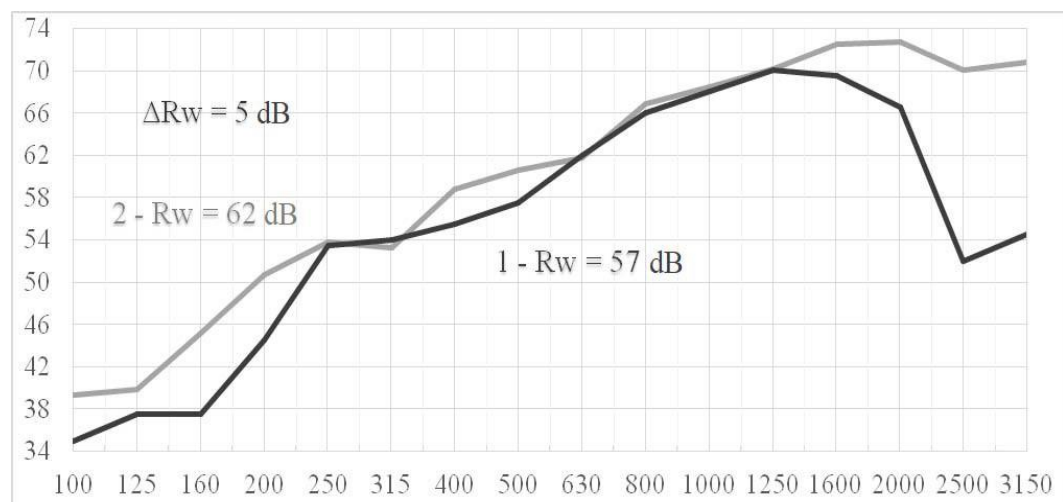

Fig. 11. Effect of the material of frame facing sheets: 1 - sheathed with 2 gypsum fiber boards, with surface density of $12 \mathrm{~kg} / \mathrm{m} 2$ and thickness of $12.5 \mathrm{~mm}, 2$ - sheathed with 2 gypsum fiber boards, with surface density of $19.5 \mathrm{~kg} / \mathrm{m} 2$ and thickness of $15 \mathrm{~mm}$.

As we can see from fig. 11, due to the higher density of gypsum fiber boards, the surface density of the structure increases, therefore, the efficiency of the structure increases according to the same mass law [7], hence the difference between the partitions $\Delta \mathrm{Rw}=5$ $\mathrm{dB}$ is arising.

\subsection{Effect of the divided base on the sound insulation of the partition installed on the double frame}

To study the effect of a divided base on which a frame partition is installed, fragments of partitions with dimensions of $2000 \times 1200 \mathrm{~mm}$ on a double independent frame made of PS $100 / 40 \mathrm{~mm}$, PN 100/37 mm, $0.6 \mathrm{~mm}$ thick are considered (the distance between the frame profiles is the same in both cases $-10 \mathrm{~mm}$ ), sheathed on each side with 2 gypsum fiber boards with surface density of $12 \mathrm{~kg} / \mathrm{m}^{2}$ and thickness of $12.5 \mathrm{~mm}$ with filling the inner space with sound-absorbing mineral wool plate with density of $35 \mathrm{~kg} / \mathrm{m}^{3}, 50 \mathrm{~mm}$ thick in two layers. The structures are installed on different bases: 1 - on a combined base, $2-$ on a divided base using damping gaskets made of glass-fiber mat, $8 \mathrm{~mm}$ thick, the perimeter joints are treated with silicone sealant.

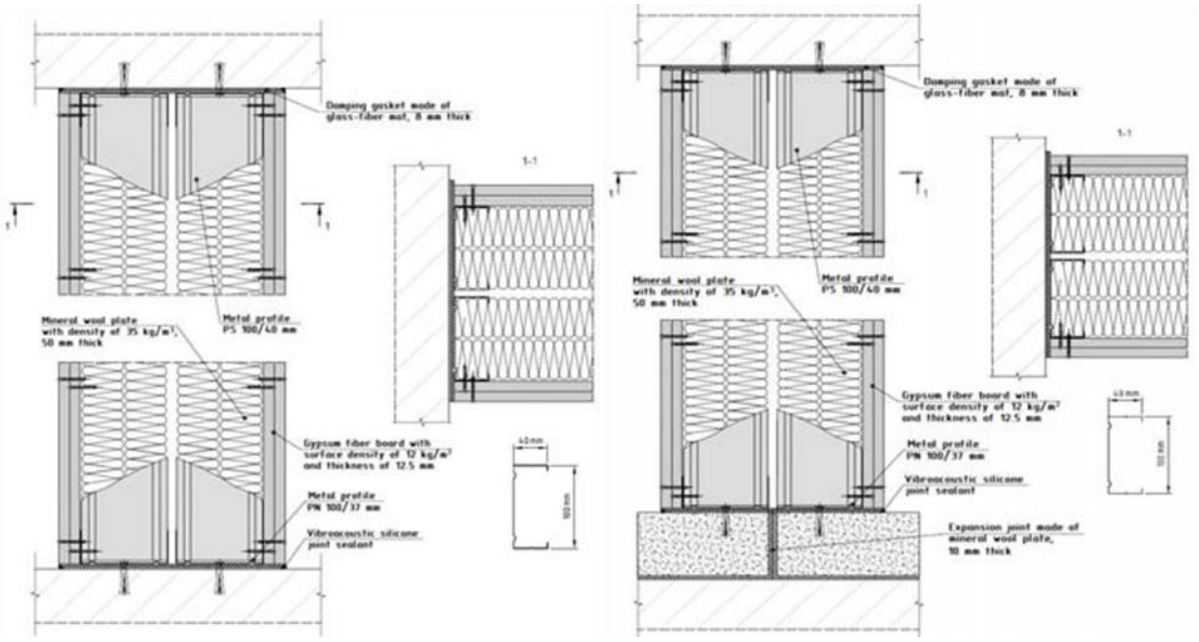

Fig. 12. Diagram of constructing the frame partitions on a double metal frame on various bases: 1 - on a combined base, 2 - on a divided base. 


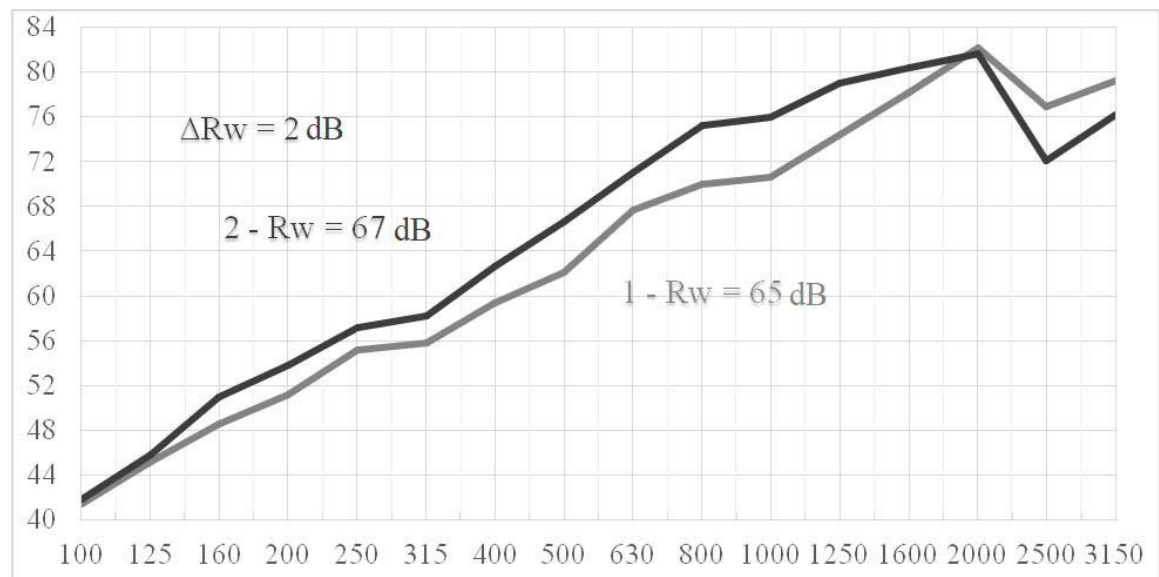

Fig. 13. Effect of the divided base, on which the frame partition is installed, on its sound insulation: 1on a combined base, 2 - on a divided base.

From the graph of laboratory measurements of sound insulation of frame partitions installed on various bases, shown in Fig. 13, we see that thanks to the construction of a double metal frame on divided bases, we get an improvement in the sound insulation of the structure $\Delta$ $\mathrm{Rw}=2 \mathrm{~dB}$.

\section{Conclusion}

According to the results of the study, it can be concluded that there are certain design features that affect the sound insulation of multilayer frame-sheathing structures, which may not be taken into account during designing, but are critically important, for example: the frame material of the future partition, due to which the difference between wood and metal frame reaches $8 \mathrm{~dB}$; section of the metal profile, thanks to the change of which one can get an increase of up to $3 \mathrm{~dB}$. Also, during the comparison, the effect of the presence and density of the sound absorber was considered; due to the presence of a damping layer the sound insulation index of the structure increases to $5 \mathrm{~dB}$. The effect of constructing the double frame on divided bases has been studied. Undoubtedly, the considered features must be taken into account when choosing a structure and materials in designing sound insulating frame partitions in civil buildings.

\section{References}

1. Basner, M., Babisch, W., Davis, A., Brink, M., Clark, C., Janssen, S., \& Stansfeld, S. (2014). Auditory and non-auditory effects of noise on health. Lancet (London, England), 383(9925), 1325-1332.

2. Resolution of the Government of the Russian Federation of December 26, $2014 \mathrm{~N}$ 1521 (as amended on December 7, 2016) "On the approval of the list of national standards and sets of rules (parts of such standards and sets of rules), as a result of which, on a mandatory basis, compliance with the requirements of the Federal Law "Technical Regulations on safety of buildings and structures" is ensured".

3. Set of rules 51.13330.2011 (2011) Sound protection, updated version of SNiP (Construction Standards and Regulations) 23-03-2003: Gosstroy of Russia (the Russian Federation State Committee for Construction, Architectural and Housing 
Policy), Federal State Unitary Enterprise "Center of design products in construction" (FGUP CPP).

4. Fadeev A. S, Tsukernikov I. E. (2019) Assessment of the insulation of airborne noise of an interroom partition made of porous materials of low bulk density [Otsenka izolyatsii vozdushnogo shuma mezhkvartirnoy peregorodki iz porizovannykh materialov nevysokoy ob'yemnoy plotnosti], Proc. of IV AllRussian Conf. of young scientists and specialists "Acoustics of the environment 2019", Moscow.

5. Kryshov S.I. (2019) Field measurements of sound insulation in new buildings in Moscow [Naturnyye izmereniya zvukoizolyatsii v novostroykakh Moskvy], Proc. of the International Acoustic Conference (IAC) - 2019, Moscow, Feb. 01, 2019.

6. GOST 27296-87 (1988) Noise protection in building. Sound insulation of enclosures. Methods of measurement. Publishing house of standards, Moscow.

7. Set of rules 275.1325800.2016 (2017) Construction fencing of residential and public buildings. Rules of sound insulation design. Standardinform, Moscow. 